\title{
The effect of nutrition and androgens on the composition of bovine blood plasma and seminal plasma at puberty
}

\author{
BY S. BARONOS, T. MANN, L. E. A. ROWSON AND J. D. SKINNER \\ ARC Unit of Reproductive Physiology and Biochemistry, \\ University of Cambridge
}

(Received 22 August I968-Accepted 15 October 1968)

\begin{abstract}
I. Experiments on three pairs of male identical twin calves have shown that underfeeding at $2 \cdot 5^{-6}$ months of age, i.e. during the critical stage of sexual maturation, considerably delayed the process of puberty, as regards testicular androgen production as well as secretion of fructose and citric acid by the seminal vesicles.

2. There was no marked difference in the blood-plasma content of non-protein nitrogen, vitamin $A$ and carotene at 6 months, as between twins on a normal $(N)$ and low (L) plane of nutrition, although the L-twins were growing and maturing more slowly. However, the blood-plasma content of glucose and of most of the free amino acids, was slightly reduced as a result of underfeeding.

3. When at the age of 6 months two twin-pairs were castrated and injected with either testosterone or androstenedione (50 $\mathrm{mg}$ every $3 \mathrm{rd}$ day, for 2 months), the L-twins of both pairs and the $\mathrm{N}$-twin of one pair grew at a faster rate. Moreover, the concentration of nitrogen in blood plasma increased, the rise being particularly evident in the content of indispensable amino acids. This effect, however, was more pronounced in the $\mathrm{N}$ - than in the L-twins.

4. Testosterone treatment enhanced libido in the $\mathrm{N}$-twin but not in the corresponding $\mathrm{L}$-twin. Androstenedione had no effect on libido in either the $\mathrm{N}$-twin or the $\mathrm{L}$-twin. Thus, although testosterone and androstenedione both effectively promoted growth and nitrogen metabolism, androstenedione, unlike testosterone, was devoid of androgenic activity.
\end{abstract}

Pubescence in the male is influenced by many factors; one of the most important is the onset and rate of testosterone production in the testes. In the bovine the appearance of testosterone in the testes at puberty precedes by several months the production of spermatozoa. In the normally developing bull calf testosterone is already chemically detectable at I month of age, together with a much higher concentration of androstenedione, a chemically closely related steroid which, however, is devoid of androgenic activity. With advancing puberty, between $\mathrm{I}$ and 6 months of life, the testosterone content of the testes steadily rises, this rise being coupled with a characteristic decline in the androstenedione:testerone ratio, and a gradual increase in the secretory output of fructose and citric acid by the seminal vesicles (Lindner \& Mann, I960; Hay, Lindner \& Mann, 1961). In electrically induced calfejaculates fructose and citric acid usually appear at about 5 months of age, roughly coinciding with the stage when testosterone becomes the predominant hormone of the testes. Spermatozoa, however, are seldom found in bull semen before the age of 9 months, that is at a stage when seminal fructose and citric acid have already reached very high levels (Mann \& Rowson, I956).

Underfeeding affects adversely the reproductive capacity of bull calves, chiefly by retarding the endocrine activity of the testes and thereby delaying the process of sexual maturation. This maturational delay is reflected in a late onset of testosterone production, a slow-down in the change-over from androstenedione to testosterone, 
and a retarded appearance of fructose and citric acid in semen. This has been demonstrated in a number of experiments carried out with identical male twins. In each pair of twins one calf was maintained on a normal, and the other on a low plane of nutrition. The low-plane diet consisted of one-half or one-third of the normal ration. This degree of underfeeding, even if restricted to a few weeks, was found to curtail vesicles, the endocrine activity of the testes and the secretory function of the seminal severely without, however, affecting seriously the process of sperm production (Davies, Mann \& Rowson, I957; Mann, Rowson \& Hay, I960; Mann, Rowson, Short \& Skinner, I967).

The purpose of the present study was to correlate the conditions observed in the testes, seminal vesicles and semen, with changes which occur simultaneously in blood plasma. In particular, we were interested to find out whether the observed retardation of sexual maturation was due to a general calorie restriction or a specific dietary deficiency in, e.g. a vitamin, protein or amino acid, as reflected in the composition of blood plasma. The blood constituents which we have studied were glucose, vitamin $A$, total and non-protein nitrogen, amino acids and amino-sugars. In addition we have examined the blood plasma in the normal-plane and low-plane twins after castration and treatment with either testosterone or androstenedione. This was done in order to compare directly the two steroids in respect of their androgenic as well as growth-promoting and anabolic activity. Our previous studies have shown that when injected into castrated bulls, androstenedione, unlike testosterone, is incapable of reversing the involutionary post-castrate changes in the seminal vesicles (Mann et al. I960); and moreover, when injected into intact pre-puberal bull calves, androstenedione actually suppresses the normal development of the secretory function of the seminal vesicles, in spite of its growth-promoting effect on the animal as a whole (Skinner, Mann \& Rowson, r968).

\section{EXPERIMENTAL}

\section{Animals}

The three pairs of male bovine twins used in the present study were: pair no. I, Friesian Ayrshire twins, born October 1964 (ser. no. XIV: Mann et al. 1967); pair no. 2, Friesian twins, born September I966 (ser. no. XVII: Skinner et al. 1968); and pair no. 3, Friesian twins, born October 1966 (ser. no. XIX: Skinner et al. I968). The routine procedure was to rear the twins belonging to each pair under identical conditions up to the age of 2.5 months, and then to feed one of them on a normal plane of nutrition ( $\mathrm{N})$, and the other on a low-plane diet (L) during the remaining period of observations, that is, 2.5-6 months in pair no. I, and 2.5-9 months in pairs no. 2 and 3 . At the age of 6 months, the pairs no. 2 and 3 were castrated bilaterally. The twins $\mathrm{N}$ and $\mathrm{L}$ belonging to pair no. 2 were then injected for a period of 2 months,

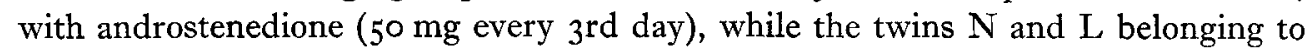
pair no. 3 were treated similarly with testosterone. Thereafter, all four calves were left without injections for I month, that is until the end of the experiment when the animals were 9 months of age. 


\section{Diet}

The composition of the daily ration fed to the N-plane calves is shown in Table $\mathrm{I}$. The L-calves received only one-third of the normal ration of milk, roots and concentrates plus one-third of the quantity of hay that had actually been consumed by the normally fed control twins on the preceding day. All animals had free access to water and mineral licks, and all received daily an identical amount of cod-liver oil, equivalent to $\mathrm{I} \%$ of the concentrates consumed by the normal-plane calves.

Table I. Daily food ration fed to the 'normal-plane' calves, from the age 2.5 months onwards

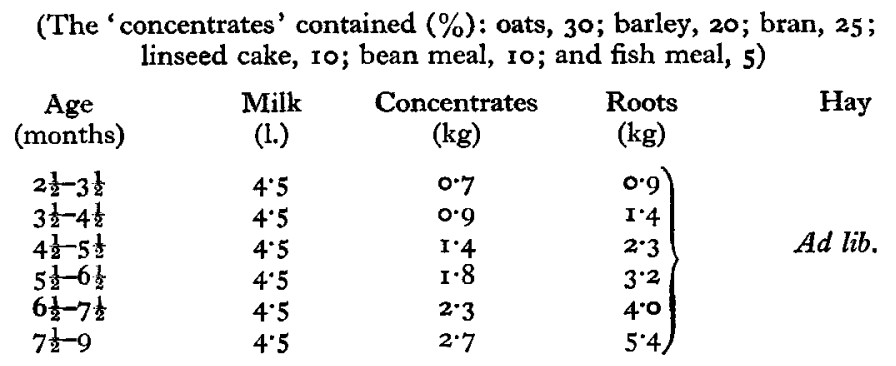

Analysis of seminal plasma

Ejaculates were collected from bull calves by electro-ejaculation (Rowson \& Murdoch, 1954), using the rectal electrode of Davies et al. (1957). Since the animals were too young to produce spermatozoa, all ejaculates collected up to the time of castration consisted entirely of seminal plasma. In these ejaculates fructose was determined by the method of Roe (1934) as adapted to semen by Mann (1946, 1948), and citric acid by the method of Speck, Moulder \& Evans (1946) as modified by Mann, Davies \& Humphrey (I949).

\section{Analysis of testes}

Details of the determination of testosterone and androstenedione are to be found in papers by Short \& Mann (1966) and Mann et al. (1967).

\section{Analysis of blood plasma}

Blood ( $50 \mathrm{ml}$ ) was collected from the jugular vein of each calf after $12 \mathrm{~h}$ fast, at monthly intervals, using heparin (250 units) as anticoagulant. Glucose was determined by the glucose oxidase-tolidine method (Middleton \& Griffiths, I957). Carotene and vitamin A were determined according to Moore (1957). The total hexosamine content of blood plasma was determined after hydrolysis in $2 \mathrm{~N}-\mathrm{H}_{2} \mathrm{SO}_{4}$ for $48 \mathrm{~h}$ at $100^{\circ}$ (in sealed tubes) according to Rondle \& Morgan (1955). Non-protein nitrogen (after deproteinization with tungstic acid) and total nitrogen were determined by the micro-Kjeldahl procedure, using Markham's distillation apparatus (King \& Wootton, I956).

Two methods were used for the determination of free amino acids. One was the 


\section{i94 S. Baronos, T. Mann, L. E. A. Rowson and J. D. Skinner ig69}

chromatographic method developed by Whitehead (1964) and Whitehead \& Dean $(1964 a, b)$ for rapid screening of the ratio between 'dispensable' and 'indispensable' amino acids in conditions associated with amino acid imbalance in children, such as kwashiorkor. For that purpose the blood plasma samples taken from the calves, were extracted with ethanol, and the ethanol-soluble material was subjected to descending chromatography so as to separate the two groups of amino acids, one, faster moving

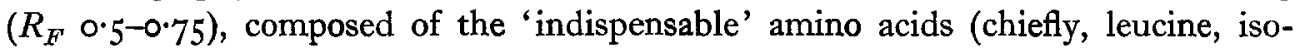
leucine, valine and methionine) and the other, slower moving $\left(R_{F}<0.5\right)$, made up of 'dispensable' amino acids. The paper chromatograms were stained with ninhydrin, then dipped into an ethanolic solution of copper nitrate, and the three main pink spots, designated according to Whitehead (1964) as I: 'leucine + isoleucine' $\left(R_{F} 0.67\right)$, II: 'valine + methionine' $\left(R_{F} \quad 0.5 \mathrm{I}\right)$, and III: 'glycine-serine-glutamine-taurine' $\left(R_{F}\right.$ ०.13) eluted with methanol. The eluate from spot III, which represents the 'dispensable' amino acids, and the combined eluates I and II, which represent together the 'indispensable' amino acids, were subjected to quantitative spectrophotometric measurement at $509 \mathrm{~m} \mu$, and the two absorption values divided by each other in order to calculate Whitehead's ratio.

The other method adopted for the analysis of free amino acids in blood plasma depended on the use of the Technicon Automatic Amino-acid Analyser. Before analysis in this instrument, the plasma samples were deproteinized with sulphosalicylic acid (го $\%$ final concentration).

\section{RESULTS}

\section{Effects on body growth and androgenic activity}

The retarding influence of underfeeding on the growth of the calves and on the onset of androgenic activity during the critical stage of male puberty, that is between 5 and 6 months of age, is evident from the values recorded in Table 2. In all three

Table 2. Effect of normal $(N)$ and low $(L)$ plane of nutrition on body-zveight and on the onset of androgenic activity in twin calves at the age 5-6 months

\begin{tabular}{|c|c|c|c|c|c|c|c|}
\hline \multirow{2}{*}{$\begin{array}{l}\text { Twin-pair } \\
\text { no. }\end{array}$} & \multirow[b]{2}{*}{ Variable measured } & \multicolumn{2}{|c|}{5 months } & \multicolumn{2}{|c|}{5.5 months } & \multicolumn{2}{|c|}{6 months } \\
\hline & & $\mathrm{N}$ & $\mathrm{L}$ & $\mathbf{N}$ & $\mathbf{L}$ & $\mathrm{N}$ & $\mathrm{L}$ \\
\hline $\mathbf{I}$ & $\begin{array}{l}\text { Body-weight }(\mathrm{kg}) \\
\text { Seminal fructose }(\mathrm{mg} / \mathrm{ro0} \mathrm{ml}) \\
\text { Seminal citric acid }(\mathrm{mg} / \mathrm{r} 00 \mathrm{ml}) \\
\text { Testosterone in testis }(\mu \mathrm{g} / \mathrm{100} \mathrm{g}) \\
\text { Androstenedione in testis }(\mu \mathrm{g} / \mathrm{I} 00 \mathrm{~g}) \\
\text { Ratio, androstenedione:testosterone }\end{array}$ & $\begin{array}{r}13 \\
13 \\
6 \\
- \\
- \\
\end{array}$ & $\begin{array}{r}75 \\
4 \\
1 \\
- \\
- \\
-\end{array}$ & $\begin{array}{r}142 \\
57 \\
45 \\
- \\
- \\
-\end{array}$ & $\begin{array}{r}82 \\
4 \\
1 \\
- \\
- \\
-\end{array}$ & $\begin{array}{r}156 \\
110 \\
78 \\
20 \cdot 7 \\
6 \cdot 7 \\
0 \cdot 3\end{array}$ & $\begin{array}{l}88 \\
5 \\
I \\
4 \cdot 1 \\
9 \cdot 2 \\
2 \cdot 2\end{array}$ \\
\hline 2 & $\begin{array}{l}\text { Body-weight }(\mathrm{kg}) \\
\text { Seminal fructose }(\mathrm{mg} / \mathrm{r} 00 \mathrm{ml})\end{array}$ & $\begin{array}{r}136 \\
40\end{array}$ & $\begin{array}{r}97 \\
3\end{array}$ & $\begin{array}{r}150 \\
50\end{array}$ & $\begin{array}{r}100 \\
8\end{array}$ & $\begin{array}{r}166 \\
65\end{array}$ & $\begin{array}{r}103 \\
14\end{array}$ \\
\hline 3 & $\begin{array}{l}\text { Body-weight }(\mathrm{kg}) \\
\text { Seminal fructose }(\mathrm{mg} / \mathrm{t} 00 \mathrm{ml})\end{array}$ & $\begin{array}{r}147 \\
30\end{array}$ & $\begin{array}{r}93 \\
3\end{array}$ & $\begin{array}{r}162 \\
47\end{array}$ & $\begin{array}{r}100 \\
6\end{array}$ & $\begin{array}{r}182 \\
95\end{array}$ & $\begin{array}{r}110 \\
20\end{array}$ \\
\hline
\end{tabular}

pairs of twins, the control twin $(\mathrm{N})$ grew more rapidly and developed secretory activity in its seminal vesicles faster than the underfed twin brother (L). At the age of 6 months, the three $\mathrm{N}$-twins belonging to the twin pairs no. I, 2 and 3, contained 
in their electro-ejaculates 110,65 and $95 \mathrm{mg}$ fructose/100 $\mathrm{ml}$, respectively, whereas in the three L-twins the corresponding values were 5,14 and $20 \mathrm{mg} / 100 \mathrm{ml}$.

When they attained the age of 6 months, two twin-pairs, namely no. 2 and 3 , were castrated, and from then on for 2 months, one pair (no. 2) was treated with androstenedione, and the other (no. 3) with testosterone. In the androstenedione-treated pair, no signs of masculine behaviour in either the $\mathrm{N}$-twin or the L-twin were evident as a result of the hormonal treatment. In contrast, in the testosterone-treated pair, the $\mathrm{N}$-twin, but not the L-twin, responded to hormonal treatment with a definite show of libido. However, both testosterone as well as androstenedione had a marked growth-promoting effect. It can be seen from Table 3 that the rate of body growth became distinctly higher during the 2-month period of hormonal treatment in the androstenedione-treated L-twin and in the testosterone-treated $\mathrm{L}$ - and $\mathrm{N}$-twin. However, when the hormone administration was terminated, the rate of gain declined again, both in the androstenedione- and testosterone-treated pairs.

\title{
Table 3. Mean daily gain in body-weight $(\mathrm{kg})$ in the two twin-pairs
} of calves nos. 2 and 3

\begin{abstract}
(One twin in each pair was maintained throughout on a normal-plane $\operatorname{diet}(\mathrm{N})$, and the other was transferred to a low-plane diet (L) during the period 2.5 to 9 months of age. At 6 months both pairs were castrated and then, for 2 months, the pair no. 2 was injected with androstenedione ( $50 \mathrm{mg}$ every 3 rd day), and the pair no. 3 was treated similarly with testosterone. Thereafter, both pairs were left without injections for 1 month)
\end{abstract}

\begin{tabular}{cl}
$\begin{array}{c}\text { Twin-pair } \\
\text { no. }\end{array}$ & \multicolumn{1}{c}{ Age (months) } \\
2 & $4-6$ (before injections) \\
& $6-8$ (androstenedione injections) \\
& $8-9$ (no injections) \\
3 & $4-6$ (before injections) \\
& 6-8 (testosterone injections) \\
& 8-9 (no injections)
\end{tabular}

\begin{tabular}{|c|c|}
\hline \multicolumn{2}{|c|}{ Mean daily gain (kg) } \\
\hline $\mathbf{N}$ & $\mathrm{L}$ \\
\hline 0.99 & 0.40 \\
\hline $\begin{array}{l}0.95 \\
0.68\end{array}$ & $\begin{array}{l}0.75 \\
0.38\end{array}$ \\
\hline $\mathbf{r} \cdot 03$ & 0.37 \\
\hline $\begin{array}{l}1 \cdot 32 \\
0.84\end{array}$ & $\begin{array}{l}0.65 \\
0.55\end{array}$ \\
\hline
\end{tabular}

\section{Effects on blood plasma}

Glucose. The results of glucose analyses in blood plasma samples taken from the twin-pairs no. 2 and 3 at the start of differential feeding (2.5 months), during the pre-castration period $(2 \cdot 5-6$ months), at the end of the 2-month treatment with androstenedione and testosterone ( 8 months), and finally at the time when the experiment was terminated (9 months), are given in Fig. I. It can be seen that on most occasions the glucose values in the undernourished calves were slightly below those of the controls, and that the differences became even less marked during the period of treatment with either androstenedione or testosterone.

Nitrogen (total and non-protein), carotene and vitamin $A$, and the ratio between 'dispensable' and 'indispensable' amino acids. The relevant findings are presented in Table 4 , where those differences between the $\mathrm{N}$ - and L-twins which were significant at either the $\leqslant I \%$ level $(* *)$ or at the $\leqslant 0.1 \%$ level $(* * *)$, are specially indicated. When the values in Table 4 are compared with those in Table 2 , it becomes immedi- 
ately obvious that, at the time of puberty, the blood-plasma composition suffered. much less from underfeeding, than the seminal plasma. After a 3.5 months' period of differential feeding, that is at the age of 6 months, the L-twins did not differ
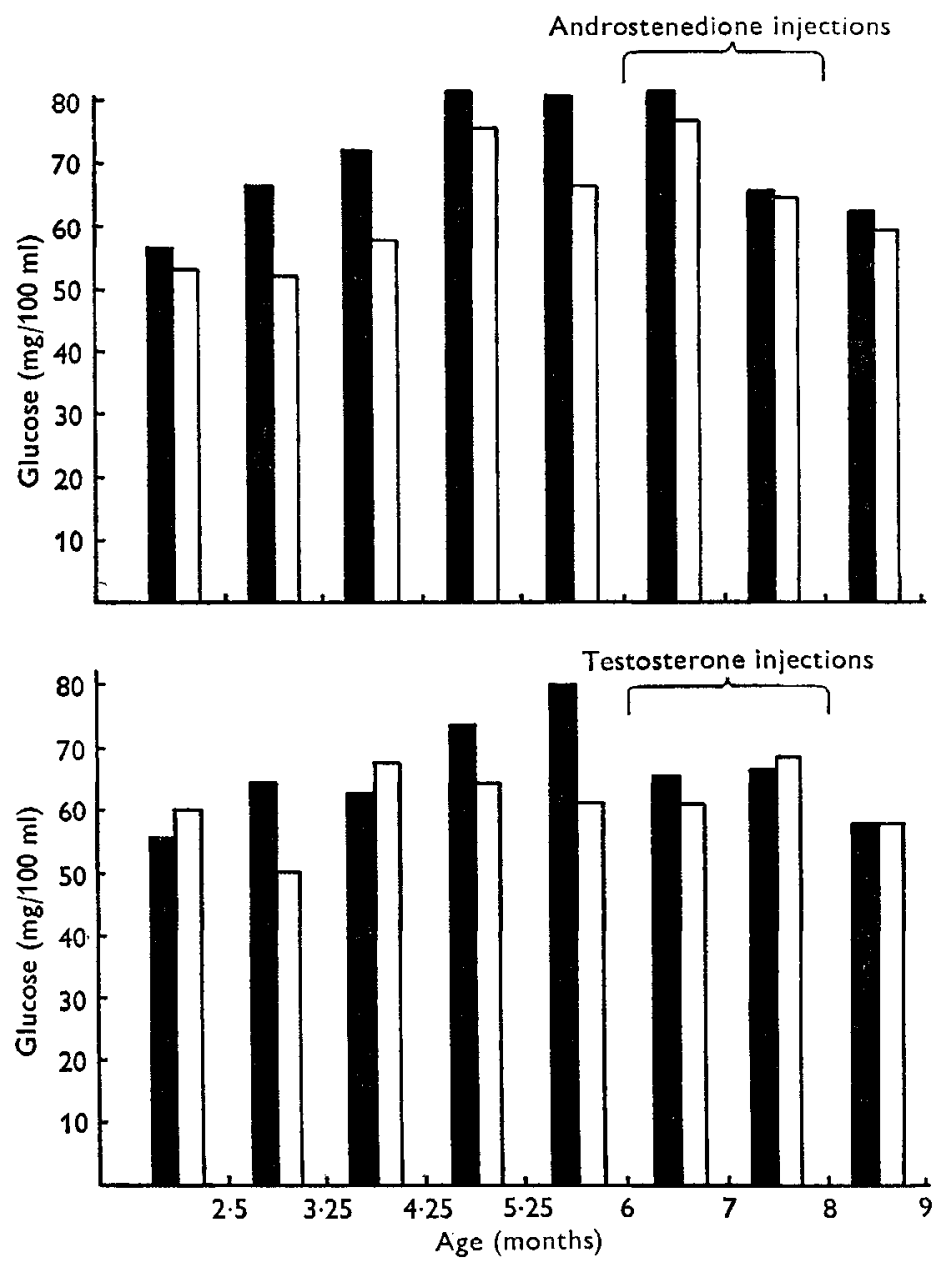

Fig. I. Glucose concentration in blood plasma samples taken from the normally fed ( $\square$ ) and underfed $(\square)$ calves of the two pairs of twins, nos. 2 and 3 , which were castrated at 6 months, and treated during the period from 6 to 8 months of age with androstenedione and testerone respectively.

essentially from the corresponding $\mathrm{N}$-twins in respect of the plasma levels of nonprotein nitrogen, vitamin $A$ and carotene. However, as regards the total nitrogen of plasma, in one of the two pairs (no. 3) the value in the L-twin was significantly (at the $\leqslant \mathrm{I} \%$ level) below that in the $\mathrm{N}$-twin. As regards the free amino acids, the close similarity between the plasma patterns of the $\mathrm{N}$ - and L-twin at 6 months of age can be plainly seen in Pl. I, which illustrates the chromatograms obtained by Whitehead's (1964) method in plasma samples from one twin-pair (no. 3). The results of spectrophotometric measurements performed on the material eluted from these 


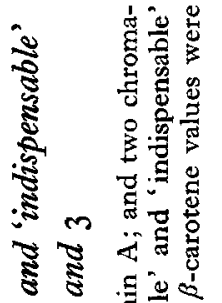

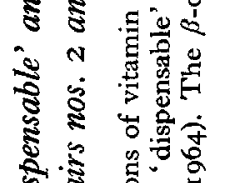

矛

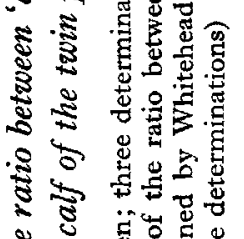

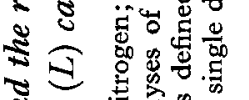

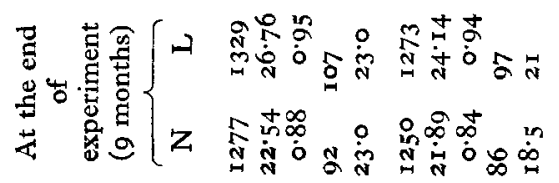

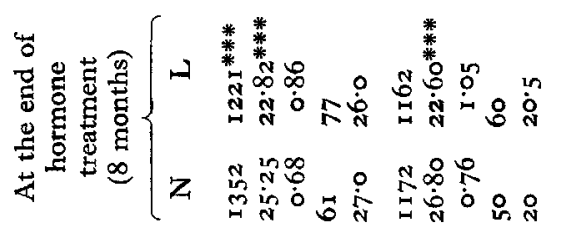

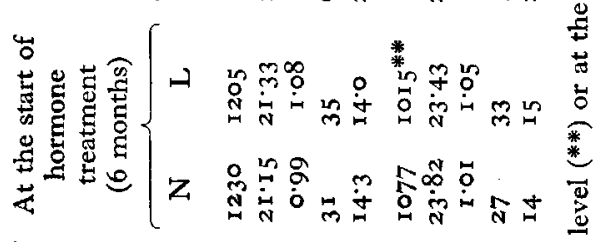

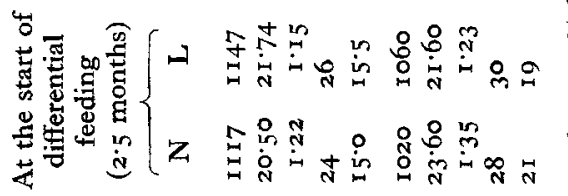

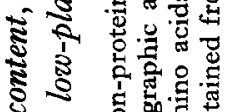

ब

过高哭

胥

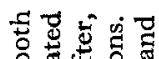

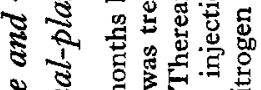

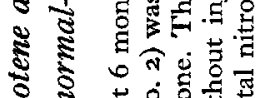

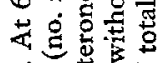

ฐ

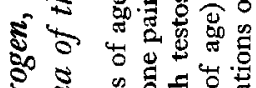

辛

क

. $\overrightarrow{2}$ ह

น

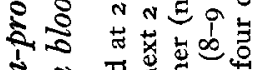

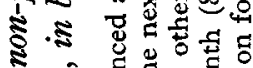

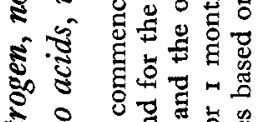

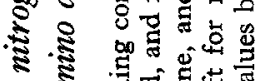

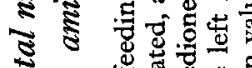

है

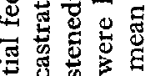

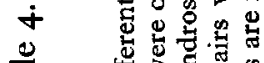

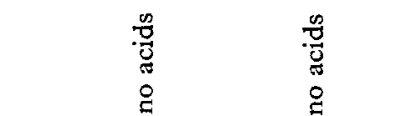

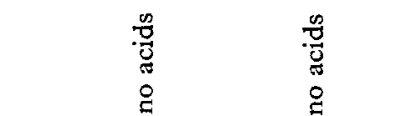

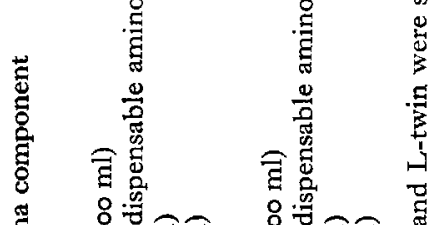

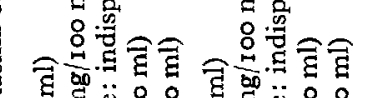

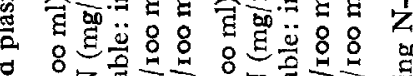

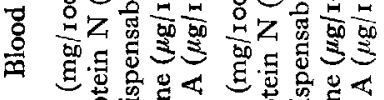

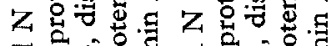

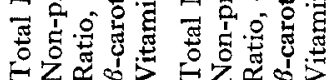




\section{i98 S. Baronos, T. Mann, L. E. A. Rowson and J. D. Skinner ig69}

chromatograms, are presented in Table 4 as the ratio between 'dispensable' and 'indispensable' amino acids. From 'Table 4 it can be seen that as a result of 2 months' treatment in both the androstenedione- and testosterone-treated twin-pair there was a distinct increase in the plasma content of total nitrogen, non-protein nitrogen, carotene, and vitamin $A$, these increases however, being much more marked in the $\mathrm{N}$-twins than in the L-twins. For non-protein nitrogen in particular, the differences between the

Table 5. Effect of androstenedione and testosterone on the concentration ( $\mu$ moles/100 ml) of free amino acids in the blood plasma of castrated twin calves maintained on normalplane $(N)$ or low-plane $(L)$ nutrition

(In one twin-pair (no. 2) the amino acid analyses were carried out both at the start (6 months) and at the end ( 8 months) of androstenedione treatment, in the other twin-pair (no. 3 ) only at the end ( 8 months) of testosterone treatment)

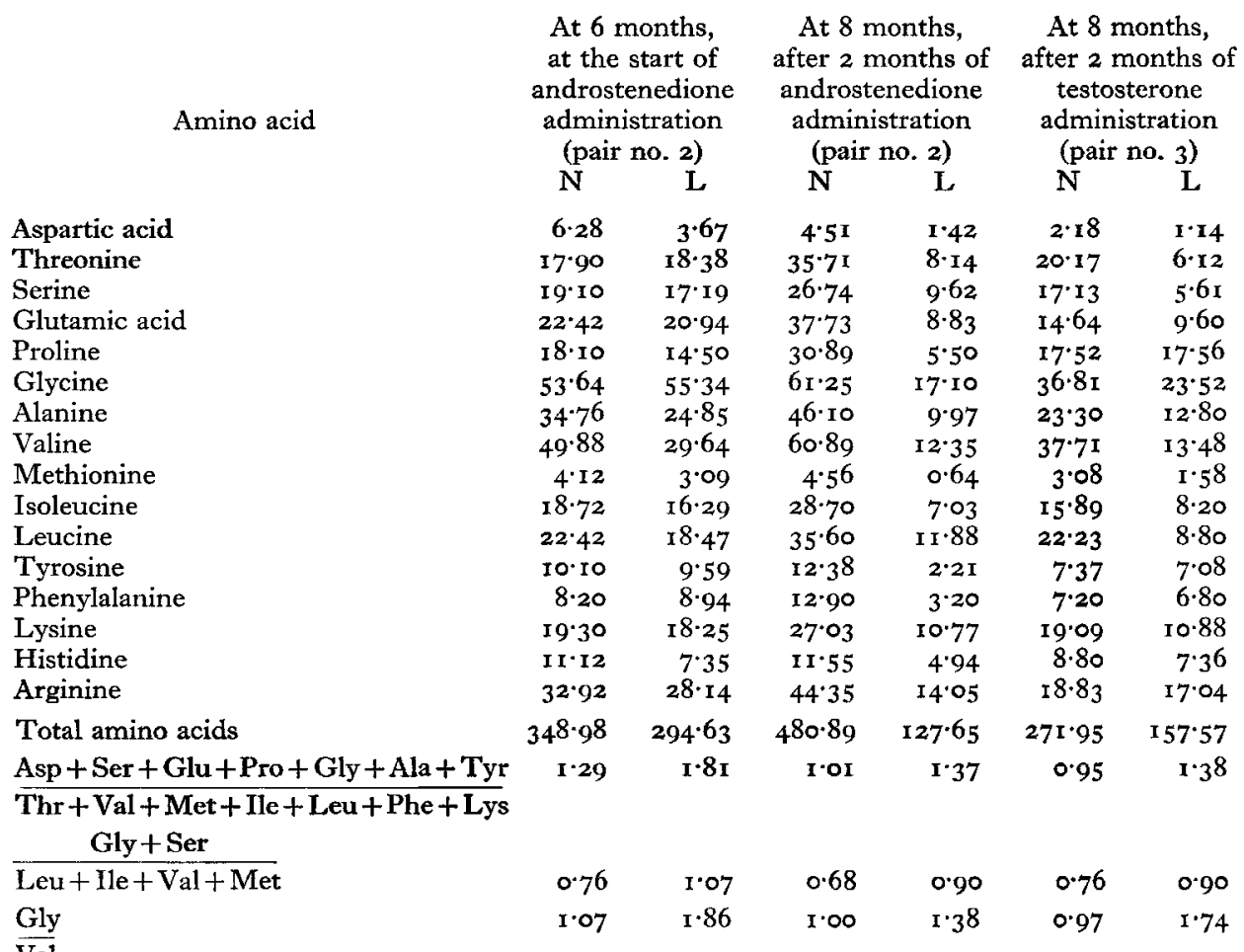

$\mathrm{N}$-twins and the L-twins became highly significant. As regards the free amino acids ratio, noteworthy is the shift towards a higher proportion of the 'indispensable' amino acids, which followed treatment with either androstenedione or testosterone.

Six blood plasma samples, three from N-twins, and three from L-twins, were examined in the automatic amino acid analyser. The results, shown in Table 5, indicate that in every instance, the total sum of amino acids was distinctly higher in the N-twin than in the corresponding L-twin. The effect of androstenedione was of particular interest since, as already pointed out, this steroid, although devoid of androgenic activity, is nevertheless capable of stimulating the body growth. In the 
androstenedione-treated $\mathrm{N}$-twin, the total sum of amino acids determined in the automatic analyser was $349 \mu \mathrm{moles} / \mathrm{ro0} \mathrm{ml}$ at the beginning, and $48 \mathrm{I} \mu \mathrm{moles} / \mathrm{ro0} \mathrm{ml}$ at the end, of the 2-month period of hormonal treatment. In contrast, the similarly treated $\mathbf{L}$-twin showed no increase in its amino acid level of blood plasma. The extent to which individual amino acids were influenced by underfeeding and androgen treatment can also be assessed from the values in Table 5. As a result of underfeeding, most of the amino acids in blood plasma have suffered losses, the 'indispensable', however, more than the 'dispensable' ones. This follows clearly from the values given in Table 5 for the 'dispensable': 'indispensable' amino acid ratio, which has been calculated in three different ways, as ( $\mathrm{I}$ ) Asp + Ser + Glu + Pro + Gly + Ala + Tyr:

\section{Table 6. Hexosamine concentration in acid-hydrolysed blood-plasma samples} taken from normal-plane $(N)$ and low-plane $(L)$ twin calves

(Differential feeding commenced at 2.5 months of age. Castration was performed at 6 months of age. During the 2-month period between 6 and 8 months of age, one pair of twins (no. 2) was treated with androstenedione, and the other (no. 3) with testosterone)

\begin{tabular}{|c|c|c|c|c|}
\hline \multirow{3}{*}{$\begin{array}{c}\text { Age } \\
\text { (months) }\end{array}$} & \multicolumn{4}{|c|}{ Total hexosamine (mg/100 ml plasma) } \\
\hline & \multicolumn{2}{|c|}{ Twin-pair no. 2} & \multicolumn{2}{|c|}{ Twin-pair no. 3} \\
\hline & $\mathbf{N}$ & $\mathbf{L}$ & $\mathbf{N}$ & $\mathbf{L}$ \\
\hline 25 & $88 \cdot 2$ & 74.1 & $92 \cdot 8$ & 79.0 \\
\hline $\begin{array}{l}3 \cdot 25 \\
4 \cdot 25\end{array}$ & $\begin{array}{l}77 \cdot 7 \\
89.0\end{array}$ & $\begin{array}{l}75 \cdot 8 \\
98 \cdot 0\end{array}$ & $\begin{array}{l}66 \cdot 2 \\
82 \cdot 8\end{array}$ & $\begin{array}{l}73 \cdot 0 \\
78 \cdot 1\end{array}$ \\
\hline 5.25 & $109 \cdot 0$ & $87 \cdot 4$ & $92 \cdot 5$ & $74^{\circ} 9$ \\
\hline 6 & 103.4 & $85 \cdot I$ & $90 \cdot 7$ & $77 \cdot 6$ \\
\hline 7 & $92 \cdot 4$ & 85.5 & $86 \cdot 5$ & $86 \cdot 3$ \\
\hline 8 & $108 \cdot 4$ & $87 \cdot 4$ & $90 \cdot 7$ & $92 \cdot 2$ \\
\hline 9 & $98 \cdot 9$ & $8 I \cdot 5$ & $96 \cdot I$ & $86 \cdot 7$ \\
\hline
\end{tabular}

$\mathrm{Thr}+\mathrm{Val}+\mathrm{Met}+\mathrm{Ile}+\mathrm{Leu}+\mathrm{Phe}+\mathrm{Lys}$, (2) Gly + Ser: Leu + Ile + Val + Met, and (3) Gly: Val. Irrespective of how the ratio is calculated, the conclusion is the same, namely, that underfeeding depresses the 'indispensable' more than the 'dispensable' amino acids of blood plasma. These calculations also show that as a result of treatment with androstenedione there was an improvement in the ratio between the 'indispensable' and 'dispensable' amino acids.

In addition to the plasma constituents mentioned, the analyses included total hexosamine, that is after acid hydrolysis. It was found (Table 6) that throughout the whole period of differential feeding, the $\mathrm{N}$-twins contained mostly a little more bound hexosamine in blood plasma than the L-twins. The differences, however, were not statistically significant. There was no evidence that the amino-sugar content of blood plasma is influenced by treatment with either androstenedione or testosterone.

\section{DISCUSSION}

Protein and vitamin A deficiency, singly or combined, constitute a well-recognized hazard to animal reproduction, and a direct link between the two forms of nutritional defect is established when, as a result of protein scarcity, a reduction takes place in 
the level of the specific serum protein normally required as carrier for the active form of vitamin $A$ in blood (Glover \& Walker, I964). In adult bulls, a lowering of the vitamin $A$ concentration in blood serum below the level of $10-15 \mu \mathrm{g} / 100 \mathrm{ml}$ is known to be associated with various gross abnormalities in the composition of semen, and in particular a high percentage of abnormal spermatozoa (Jaśkowski, Wałkowski, Rulski, Szulc \& Kłosowski, I966). Young calves are even more susceptible to hypovitaminosis $A$ since their normal reserve of the vitamin is notoriously low at birth (Moore, 1957; Leathem, I959; Moustgaard, I959; Spratling, Bridge, Barnett, Abrams, Palmer \& Sharman, 1965; Thompson, Howell \& Pitt, I965; Jaśkowski et al. x966). On the other hand, young calves carry in their blood serum an appreciable reserve of free amino acids, which declines progressively during the first 6 months of life, that is at the time when the animals' digestion changes from the monogastric type to that of the adult ruminant (Leibholz, 1966). Suitable protein supplements added to the diet of cattle can, however, increase the concentration of amino acids in serum while underfeeding, or conditions such as lactation, which imposes an exceptional drain on the amino acid reserve, can produce the opposite effect (Leibholz, I966; Halfpenny \& Rook, I968).

Our previous studies have shown that an immediate and most obvious result of general underfeeding in the male pubescent calf is a marked retardation of pubescence, the main cause being (I) a lowered gonadotrophic activity of the pituitary gland, so that too little gonadotrophin reaches the testes, and insufficient testosterone is produced in the testes, and (2) a reduced response of male accessory organs to testosterone stimulation (Davies et al. 1957; Mann, 1967; Mann et al. 1960, 1967). In the present series of experiments, which involved three pairs of male identical twin calves, underfeeding was of a relatively moderate degree and brief duration, so that the low-plane twins were still able to gain weight, though more slowly than the normally fed controls. However, the inhibitory effect of underfeeding on the process of male pubescence was very strong indeed, as the underfed twins lagged distinctly in their ability to generate testosterone in the testes and secrete fructose in the seminal plasma. At puberty, after 3.5 months of underfeeding, the content of nonprotein nitrogen, vitamin $A$ and carotene in the blood plasma of the underfed animals differed little from that of the normally fed controls. The concentration of most of the free amino acids (thirteen out of sixteen), however, was reduced, and so was the content of glucose. The reduction was not great. Nevertheless, it does not rule out the possibility that in addition to a general calorie deficit, the retardation of growth and sexual development had been caused specifically, at least to some extent, by an amino acid or carbohydrate deficiency.

When after 3.5 months of differential feeding, followed by castration, one L-twin was injected with testosterone and the other L-twin with androstenedione, both responded with an increase in the rate of body growth, and in addition, the androstenedione-treated animal showed a marked improvement in the 'indispensable': 'dispensable' amino acid ratio of blood plasma. While, however, testosterone stimulated both growth and male sexual activity, androstenedione acted as an efficient growth-promoter but was free from androgenic effects. 


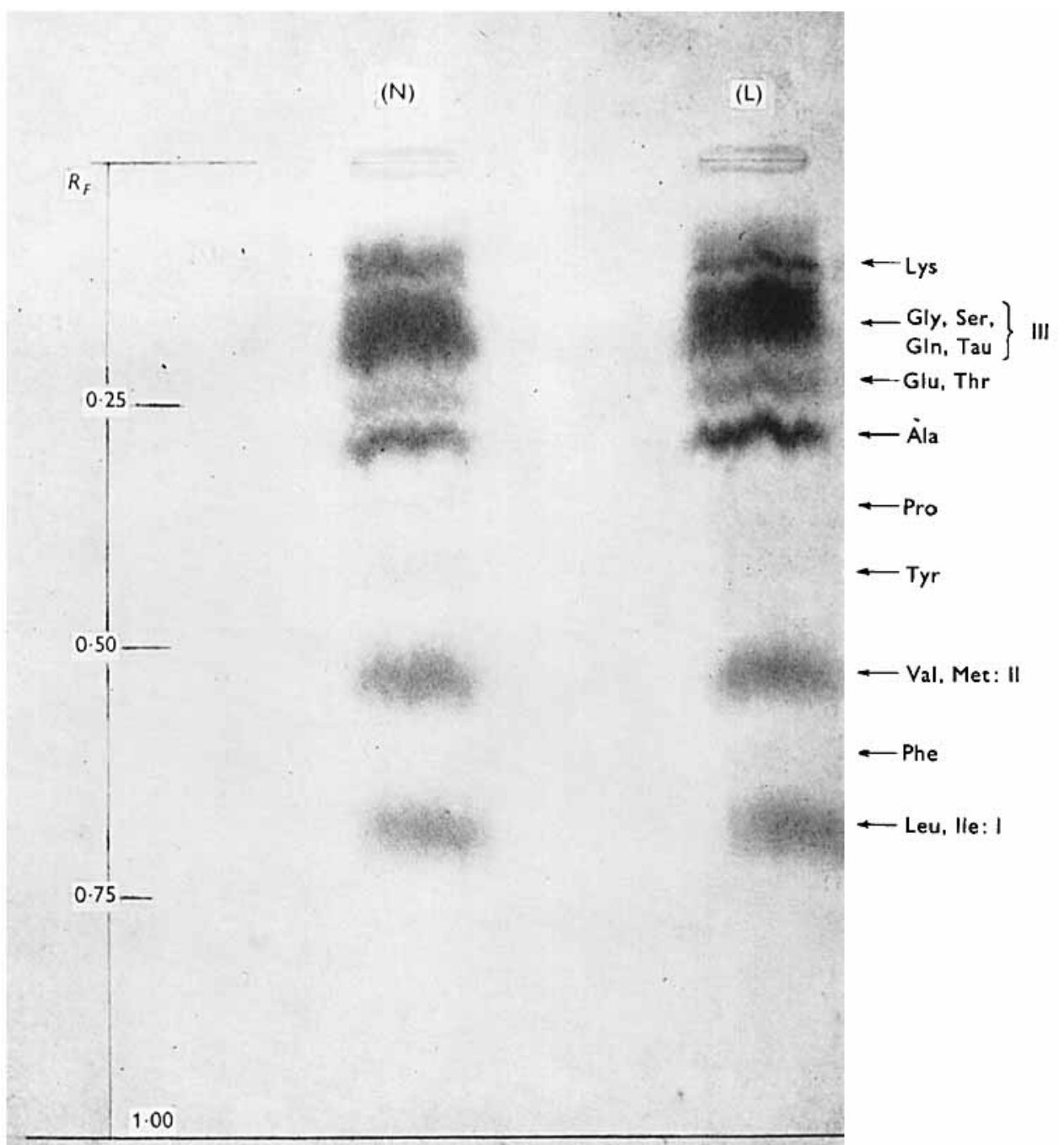


This study was carried out on behalf of the Agriculture Research Council. S. Baronos (Greece) was in receipt of a scholarship from the Organization for Economic Co-operation and Development, and J. D. Skinner (South Africa) in receipt of a scholarship from the British Petroleum Company. The authors wish to acknowledge gratefully the advice and help received from Dr A. Coward, Dr J. C. R. Thorne and Dr R. G. Whitehead.

\section{REFERENCES}

Davies, D. V., Mann, T. \& Rowson, L. E. A. (1957). Proc. R. Soc. B 147, 332.

Glover, J. \& Walker, R. J. (1964). Exp. Eye Res. 3, 374.

Halfpenny, A. F. \& Rook, J. A. F. (I968). Proc. Nutr. Soc. 27, 19A.

Hay, M. F., Lindner, H. R. \& Mann, T. (I96I). Proc. R. Soc. B 154, 433.

Jaśkowski, L., Wałkowski, L., Rulski, T., Szulc, L. \& Kłosowski, B. (1966). Polskie Archwm wet. ro, I9I.

King, E. J. \& Wootton, I. D. P. (1956). Micro-analysis in Medical Biochemistry. London: J. and A. Churchill.

Leathem, J. H. (1959). Reproductive Physiology and Protein Nutrition. New Brunswick: Rutgers University Press.

Leibholz, J. (1966). Aust. F. agric. Res. 17, 237.

Lindner, H. R. \& Mann, T. (I960). $\mathcal{~ F . ~ E n d o c r . ~ 2 1 , ~ 3 4 1 . ~}$

Mann, T. (1946). Biochem. F. 40, $48 \mathrm{I}$.

Mann, T. (1948). F. agric. Sci. 38, 323 .

Mann, T. (1967). Ciba Fdn Colloq. Endocr. x6, 233.

Mann, T., Davies, D. V. \& Humphrey, G. F. (1949). F. Endocr. 6, 75.

Mann, T. \& Rowson, L. E. A. (1956). Proc. int. Congr. Anim. Reprod. III. Cambridge I, 2 I.

Mann, T., Rowson, L. E. A. \& Hay, M. F. (1960). F. Endocr. 21, 36I.

Mann, T., Rowson, L. E. A., Short, R. V. \& Skinner, J. D. (1967). F. Endocr. 38, 455.

Middleton, J. E. \& Griffiths, W. J. (1957). Br. med. F. ii, I525.

Moore, T. (1957). Vitamin A. Amsterdam: Elsevier Publishing Company.

Moustgaard, J. (1959). In Reproduction in Domestic Animals. Vol. 2, p. 169. [H. H. Cole and P. T. Cupps, editors.] New York and London: Academic Press Inc.

Roe, J. H. (1934). F. biol. Chem. ro7, 15.

Rondle, C. J. M. \& Morgan, W. T. J. (1955). Biochem. F. 6x, 586.

Rowson, L. E. A. \& Murdoch, M. I. (1954). Vet. Rec. 66, 326.

Short, R. V. \& Mann, T. (1966). F. Reprod. Fert. 12, 337.

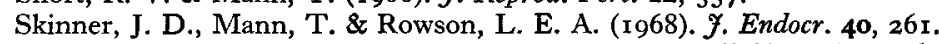

Speck, J. F., Moulder, J. W. \& Evans, E. A. Jr (1946). F. biol. Chem. 164, 119.

Spratling, F. R., Bridge, P. S., Barnett, K. C., Abrams, J. T., Palmer, A. C. \& Sharman, I. M. (1965). Vet. Rec. 77, 1532 .

Thompson, J. N., Howell, J. McC. \& Pitt, G. A. J. (1965). In Agents Affecting Fertility, p. 34. [C. R Austin and J. S. Perry, editors.] London: J. and A. Churchill.

Whitehead, R. G. (1 964). Lancet i, $25^{\circ}$.

Whitehead, R. G. \& Dean, R. F. A. (r964a). Am. F. clin. Nutr. 14, 313.

Whitehead, R. G. \& Dean, R. F. A. (1964b). Am. Y. clin. Nutr. 14, 320.

\section{EXPLANATION OF PLATE}

Pl. I. Free amino acids separated chromatographically according to Whitehead (1964) from blood plasma of a normal-plane (left) and a low-plane (right) twin calf at 6 months of age. The three spots, marked I, II and III were eluted, and the eluates analysed spectrophotometrically. The ratio between the 'dispensable' and 'indispensable' amino acids was III/(I + II). 